Jap. J. M. Sc. \& Biol., 11, 467-481, 1958

\title{
EPIDEMIOLOGICAL STUDIES OF AN OUTBREAK OF EPIDEMIC KERATOCONJUNCTIVITIS IN OGAKI CITY AND ITS VICINITY, GIFU PREFECTURE IN 1957
}

\author{
Hideo FUKUMI, Fumio NISHIKAWA, \\ Department of Bacteriology, National Institute of Health, Tokyo \\ UzUHIKo KURIMOTO, HiRomasa INOUE \\ Prefectural Public Health Laboratory, Gifu \\ Jiro USUI \\ Ogaki Health Center, Ogaki, Gifu \\ AND TAKESHI HIRAYAMA \\ Department of Epidemiology, National Institute of Public Health, Tokyo
}

(Received: December 17th, 1958)

Since Jawetz, Nicholas, Thygeson and Hanna (1955) isolated adenovirus type 8 as a causative agent from a case of epidemic keratoconjunctivitis, considerable attention has been paid to the etiology of this disease entity (Jawetz, Kimura, Hanna, Coleman, Thygeson and Nicholas, 1955; Jawetz, Thygeson, Hanna, Nicholas and Kimura, 1956 ; Mitsui and Jawetz, 1957 ; Leopold, 1957 ; Sommerville, 1957 ; 1958), including human volunteer experiments (Mitsui, Hanabusa, Minaoda and Ogata, 1957 ; Jawetz, Thygeson, Hanna, Nicholas and Kimura, 1957).

In September, 1957, an epidemic keratoconjunctivitis was encountered in Ogaki City, Gifu Prefecture and its vicinity, and about 100 school children were presumed to be involved in it, whereas many patients were of course found among other age groups. Adenovirus type 8 was isolated from some patients examined and in addition to this, some of the patients were found to show antibody rise against this virus at their convalescent sera. The present publication is devoted to describe the epidemic epidemiologically and etiologically.

\section{Laboratory Materials and Methods}

Collection of eye materials: Palpebral conjunctiva which showed inflammation was scratched with an edge of a cover glass and then the cover glass was immersed into broth and heavily shaken. This was used as a material for virus isolation.

Virus isolation: HeLa cell cultures were employed for virus isolation. The detailed technics were almost the same as those described previously (Fukumi, Nishikawa, Nakamura Watanabe and Kitayama, 1958). The inoculated HeLa cell cultures were microscopically checked either daily or at least every other day for three weeks to 26 days with weekly

福見秀雄・西川交雄（国立予防藻生研究所細茼部）；栗本珍彥・井上裕正（吱阜県衛生研究所）; 日井次郎 (岐皁県大垣保健所); 平山雄（国立公衆衛生院疫学部） 
medium change.

Typing of the isolated adenoviruses: The typing of the isolated adenoviruses was conducted by neutralization with the rabbit antisera against the adenovirus prototype strains. As the cytopathic changes due to the adenovirus type 8 appear usually a little more slowly than those due to the other type viruses, and furthermore their microscopic appearance look also somewhat different even in unstained observation from those of the others, the adenovirus type 8 strains are usually recognized as such in isolation experiments prior to serological identification. In serological examinations, the dose of adenovirus suspension which caused well-recognized cytopathic changes in HeLa cell sheets in two days after inoculation was mixed with the rabbit antiserum of each type in equal amount, and the mixture was inoculated into two HeLa cell tube cultures for each after 30 minutes' contact at room temperature. The results were read by comparing the cytopathic changes with those inoculated with the test virus alone.

Neutralization reacticn of human sera: The strain 57-140 was employed for this purpose. This strain was isolated from one of the patients in the epidemic of the present study and identified as adenovirus type 8 . For the estimation of neutralizing antibody against adenovirus type 8 , an adequate dilution of supernate of HeLa cell cultures infected with the strain $57-140$, which was preliminarily confirmed to cause well-recognizable cytopathic change in HeLa cells in 48 hours after inoculation, was mixed with each of serial two-fold dilution. The mixtures were then inoculated into HeLa cell tube cultures, two tubes for each dilution after one hour's contact at room temperature. Readings were made by comparing the grades of cytopathic changes in the inoculated HeLa cells with those of the HeLa cell cultures inoculated with the test virus alone.

\section{Description OF THE EPIDEMIC}

Ogaki City is located about 15 kilometers west of Gifu City, the capital of Gifu Prefecture, and has a population of about 100,000. On September 21, 1957, the Ogaki Health Center received a report that a kind of epidemic eye disease was prevailing in some schools in Ogaki City and was requested by the Education Committee of the city for its help to prevent and treat the disease. Subsequent examinations revealed after all that the epidemic which was elucidated to be due to epidemic keratoconjunctivitis had already started at about the middle of August, 1957, and ceased at about the end of September, 1957.

The numbers of the cases in the schools in Ogaki City involved in this epidemic of epidemic keratoconjunctivitis are shown in Table 1. The location of these schools in the city is seen in Fig. 1. It indicates that the schools located in the central part of the city were most heavily affected by the epidemic. The Minami Elementary School was most severely involved among them and thus 20.9 per cent of the school children were affected as a whole, and beside this in the Minami Middle School and the Nishi Elementary School more than 10 per cent of the student were affected.

The time-occurrence of the patients was most thoroughly surveyed in the three most severely affected schools and the results are given in Fig. 2. As is seen in the figure, there had been scattered sporadic cases of the disease already before the major course of the epidemic. This fact was also confirmed by some practitioners in ophthalmology in this city, stating that they had encountered sporadic cases of epidemic keratoconjunctivitis now and then before the epidemic outbreak. Table 3 shows the number of the cases of epidemic keratoconjunctivitis examined 
Table 1. Numbers of patients and attack rates in the schools involved in the epidemic

\begin{tabular}{|c|c|c|c|c|}
\hline \multirow{2}{*}{ School } & \multirow{2}{*}{ Sex } & \multirow{2}{*}{$\begin{array}{l}\text { Number of } \\
\text { students }\end{array}$} & \multicolumn{2}{|c|}{ Patients } \\
\hline & & & Number & Percentage \\
\hline Minami $\mathrm{E}^{\#}$ & $\begin{array}{l}\text { male } \\
\text { female } \\
\text { total }\end{array}$ & $\begin{array}{r}847 \\
822 \\
1669\end{array}$ & $\begin{array}{l}200 \\
149 \\
349\end{array}$ & $\begin{array}{l}23.6 \\
18.1 \\
20.9\end{array}$ \\
\hline Nishi E & $\begin{array}{l}\text { male } \\
\text { female } \\
\text { total }\end{array}$ & $\begin{array}{r}955 \\
882 \\
1837\end{array}$ & $\begin{array}{r}132 \\
71 \\
203\end{array}$ & $\begin{array}{r}13.2 \\
8.0 \\
11.0\end{array}$ \\
\hline Kobun E & $\begin{array}{l}\text { male } \\
\text { female } \\
\text { total }\end{array}$ & $\begin{array}{r}848 \\
799 \\
1647\end{array}$ & $\begin{array}{l}50 \\
30 \\
80\end{array}$ & $\begin{array}{l}5.9 \\
3.8 \\
4.9\end{array}$ \\
\hline Higashi E & $\begin{array}{l}\text { male } \\
\text { female } \\
\text { total }\end{array}$ & $\begin{array}{r}970 \\
914 \\
1884\end{array}$ & $\begin{array}{r}9 \\
6 \\
15\end{array}$ & $\begin{array}{l}0.9 \\
0.7 \\
0.8\end{array}$ \\
\hline Nakagawa E & $\begin{array}{l}\text { male } \\
\text { female } \\
\text { total }\end{array}$ & $\begin{array}{l}267 \\
260 \\
527\end{array}$ & $\begin{array}{r}8 \\
7 \\
15\end{array}$ & $\begin{array}{l}3.0 \\
2.7 \\
2.9\end{array}$ \\
\hline Shizusato E & $\begin{array}{l}\text { male } \\
\text { female } \\
\text { total }\end{array}$ & $\begin{array}{l}203 \\
168 \\
371\end{array}$ & $\begin{array}{r}8 \\
5 \\
13\end{array}$ & $\begin{array}{l}3.9 \\
2.9 \\
3.5\end{array}$ \\
\hline Uruu E & $\begin{array}{l}\text { male } \\
\text { female } \\
\text { total }\end{array}$ & $\begin{array}{l}356 \\
330 \\
686\end{array}$ & $\begin{array}{l}4 \\
1 \\
5\end{array}$ & $\begin{array}{l}1.1 \\
0.3 \\
0.7\end{array}$ \\
\hline Ayasato E & $\begin{array}{l}\text { male } \\
\text { female } \\
\text { total }\end{array}$ & $\begin{array}{r}104 \\
90 \\
194\end{array}$ & $\begin{array}{l}5 \\
1 \\
6\end{array}$ & $\begin{array}{l}4.8 \\
1.1 \\
3.1\end{array}$ \\
\hline Kono E & $\begin{array}{l}\text { male } \\
\text { female } \\
\text { total }\end{array}$ & $\begin{array}{l}308 \\
276 \\
584\end{array}$ & $\begin{array}{l}2 \\
2 \\
4\end{array}$ & $\begin{array}{l}0.6 \\
0.7 \\
0.7\end{array}$ \\
\hline Kita E & $\begin{array}{l}\text { male } \\
\text { female } \\
\text { total }\end{array}$ & $\begin{array}{r}644 \\
579 \\
1223\end{array}$ & $\begin{array}{l}3 \\
0 \\
3\end{array}$ & $\begin{array}{l}0.5 \\
0.0 \\
0.2\end{array}$ \\
\hline Nisshin E & $\begin{array}{l}\text { male } \\
\text { female } \\
\text { total }\end{array}$ & $\begin{array}{l}175 \\
176 \\
351\end{array}$ & $\begin{array}{l}1 \\
0 \\
1\end{array}$ & $\begin{array}{l}0.6 \\
0.0 \\
0.3\end{array}$ \\
\hline Minami $\mathrm{M}^{\# \#}$ & $\begin{array}{l}\text { male } \\
\text { female } \\
\text { total }\end{array}$ & $\begin{array}{l}470 \\
460 \\
930\end{array}$ & $\begin{array}{r}69 \\
35 \\
104\end{array}$ & $\begin{array}{r}14.7 \\
7.6 \\
11.2\end{array}$ \\
\hline Nishi M & $\begin{array}{l}\text { male } \\
\text { female } \\
\text { total }\end{array}$ & $\begin{array}{r}602 \\
642 \\
1244\end{array}$ & $\begin{array}{l}25 \\
27 \\
52\end{array}$ & $\begin{array}{l}4.2 \\
4.2 \\
4.2\end{array}$ \\
\hline Kita M & $\begin{array}{l}\text { male } \\
\text { female } \\
\text { total }\end{array}$ & $\begin{array}{r}541 \\
548 \\
1089\end{array}$ & $\begin{array}{r}11 \\
3 \\
14\end{array}$ & $\begin{array}{l}2.4 \\
0.5 \\
1.3\end{array}$ \\
\hline Kobun M & $\begin{array}{l}\text { male } \\
\text { female } \\
\text { total }\end{array}$ & $\begin{array}{l}394 \\
422 \\
816\end{array}$ & $\begin{array}{l}6 \\
3 \\
9\end{array}$ & $\begin{array}{l}1.5 \\
0.7 \\
1.1\end{array}$ \\
\hline Higashi M & $\begin{array}{l}\text { male } \\
\text { female } \\
\text { total }\end{array}$ & $\begin{array}{r}574 \\
579 \\
1153\end{array}$ & $\begin{array}{l}2 \\
4 \\
6\end{array}$ & $\begin{array}{l}0.3 \\
0.7 \\
0.5\end{array}$ \\
\hline
\end{tabular}

\# E : Elementary School

\#\# M: Middle School. 


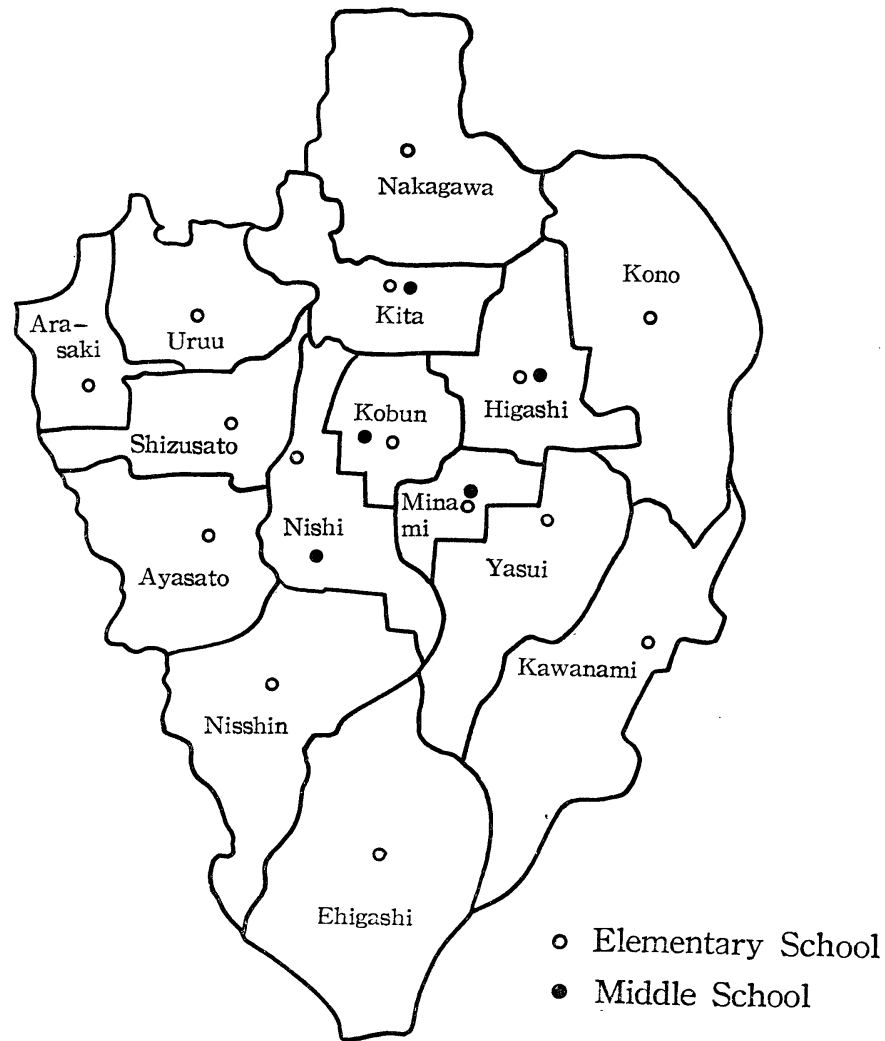

Fig. 1. Map of Ogaki City.

Table 2. Number of epidemic keratoconjunctivitis patients visiting one of the ophthalmological hospitals in the epidemic area during August to December, 1957

\begin{tabular}{crc}
\hline Month & Date & Number of patients \\
\hline August & $1-10$ & 9 \\
& $11-20$ & 4 \\
September & $21-31$ & 20 \\
& $1-10$ & 32 \\
October & $11-20$ & 66 \\
& $21-30$ & 46 \\
November & $1-10$ & 40 \\
& $11-20$ & 18 \\
December & $21-31$ & 12 \\
& $1-10$ & 8 \\
& $11-20$ & 15 \\
& $21-30$ & 12 \\
& $1-10$ & 4 \\
& $11-20$ & 6 \\
\hline
\end{tabular}




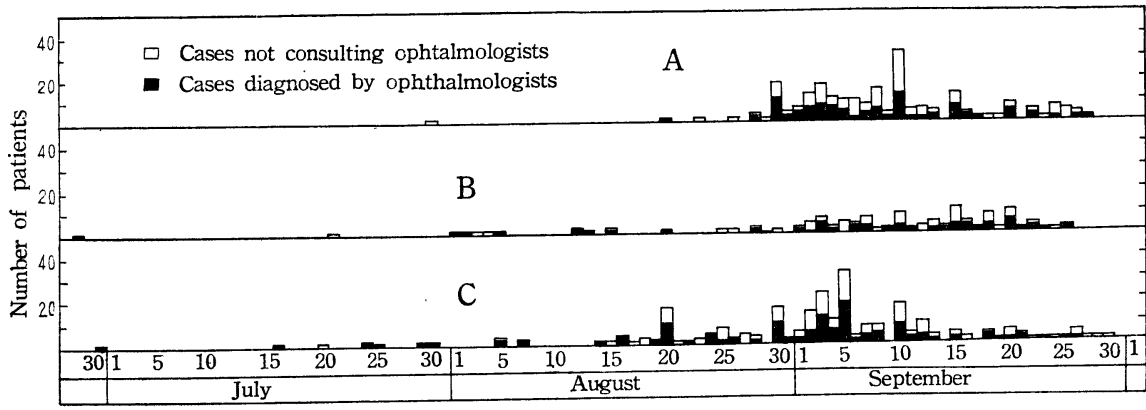

Fig. 2. Time-occurrence of epidemic keratoconjunctivitis cases in the three schools. The data is based upon the questionaires given to the school children.
A : Nishi E.
B : Minami $\mathrm{M}$.
$\mathrm{C}$ : Minami E.

Table 3. Monthly numbers of the patients of epidemic keratoconjunctivitis during 1957 in the areas where 10 or more than 10 patients were noticed during the period. The data were obtained from the protocols of four ophthalmological hospitals in the epidemic area

\begin{tabular}{|c|c|c|c|c|c|c|c|c|c|c|c|c|c|}
\hline \multirow{2}{*}{ Area } & \multicolumn{13}{|c|}{ Numbers of patients } \\
\hline & Jan. & Feb. & Mar. & Apr. & May & June & July & Aug. & Sept. & Oct. & Nov. & Dec. & Total \\
\hline $\begin{array}{l}\text { Minami- } \\
\text { wakamori }\end{array}$ & & & & & & 2 & 2 & 3 & 4 & 5 & & 1 & 17 \\
\hline Muro & & & & & & & 5 & 7 & 1 & & & 2 & 15 \\
\hline Takaya & & & & & & & 3 & 1 & 3 & 6 & 2 & 4 & 19 \\
\hline Kasanui & 1 & 1 & & & & & 3 & 3 & 2 & 1 & & & 11 \\
\hline $\mathrm{Ta}$ & & & & & & & 1 & & 7 & 1 & 2 & & 11 \\
\hline Yoyasu & & & 1 & 1 & & 3 & 2 & 1 & 7 & 2 & & 1 & 18 \\
\hline Miya & & & & & & 1 & 1 & 3 & 1 & 4 & & & 10 \\
\hline Fukuda & & & 1 & & & & 6 & 3 & 2 & 1 & 1 & & 14 \\
\hline Kiriishi & & & & & & 1 & & 4 & 10 & 1 & 1 & & 17 \\
\hline Marunouchi & & & & & & & & 2 & 8 & 4 & & & 16 \\
\hline Kirigasaki & & & & & & & 2 & 2 & 4 & & 1 & & 11 \\
\hline Kuzegawa & 1 & & & & 1 & 2 & 4 & 1 & 9 & 2 & 1 & 1 & 18 \\
\hline Funa & & & & & & & & 1 & 9 & & & & 13 \\
\hline Miwa & & & & & & 2 & 3 & 1 & 7 & & & & 12 \\
\hline Takejima & 2 & & & & & & 2 & & 9 & & & & 11 \\
\hline Hon & & & & & & & & 2 & 3 & 4 & & 1 & 10 \\
\hline Yanagi & & & & & 1 & & 3 & & 6 & 2 & 1 & 1 & 14 \\
\hline Wakamori & & & & & & 1 & 1 & 1 & 3 & 2 & 1 & 1 & 10 \\
\hline Fujie & & & & 1 & & & 1 & 1 & 12 & 5 & 1 & 2 & 23 \\
\hline Nishizaki & & & 1 & & 2 & 1 & 4 & 4 & 7 & 2 & 3 & 3 & 27 \\
\hline Midori & & & & 1 & & 1 & 6 & 11 & 2 & & 1 & 1 & 23 \\
\hline Arao & & & 1 & 1 & & 1 & 5 & 4 & 6 & 2 & 2 & & 22 \\
\hline Kitakiriishi & & & & & & 1 & & 5 & 9 & 2 & 4 & 1 & 22 \\
\hline Kanda & & & & & & 2 & 3 & 4 & 6 & 5 & & 3 & 23 \\
\hline Minaminokawa & & & & & & 2 & 8 & 3 & 12 & & & & 26 \\
\hline Motoima & & & & 1 & & 1 & 3 & 4 & 17 & 3 & 5 & 1 & 35 \\
\hline Jinai & 1 & & & & & & 2 & 8 & 19 & 1 & 2 & & 33 \\
\hline Kido & 2 & & 1 & & & 2 & 8 & 5 & 7 & 7 & & & 32 \\
\hline Kuruwa & & & & 1 & 4 & 2 & 9 & 7 & 14 & 2 & 2 & 1 & 42 \\
\hline Hayashi & & 2 & 3 & & 3 & 6 & 10 & 5 & 4 & 7 & 4 & 6 & 50 \\
\hline Muromura & & & & & 3 & & 8 & 11 & 10 & 7 & 5 & 8 & 52 \\
\hline
\end{tabular}


by one of the ophthalmological hospitals in the epidemic area since the beginning of August to the end of the year 1957. Several cases were already seen at the beginning of August, while some cases were also observed still in December 1957, when the major course of the epidemic was stated to have already ceased. It seems to mean that a factor or factors might have induced the outbreaks of the disease especially among school children from scattered sporadic cases, and further that the epidemic might have left sporadic cases in the families where it has been brought in by school children even after it had subsided.

It may be of interest in this respect to know the occurrence of the cases of this disease in the general population in Ogaki City and its vicinity during the period from January to December, 1957. Such informations were collected from the protocols of four ophthalmological hospitals (not inclnding the data of the hospital that presented Table 2). Total 1085 patients of epidemic keratoconjunctivitis were

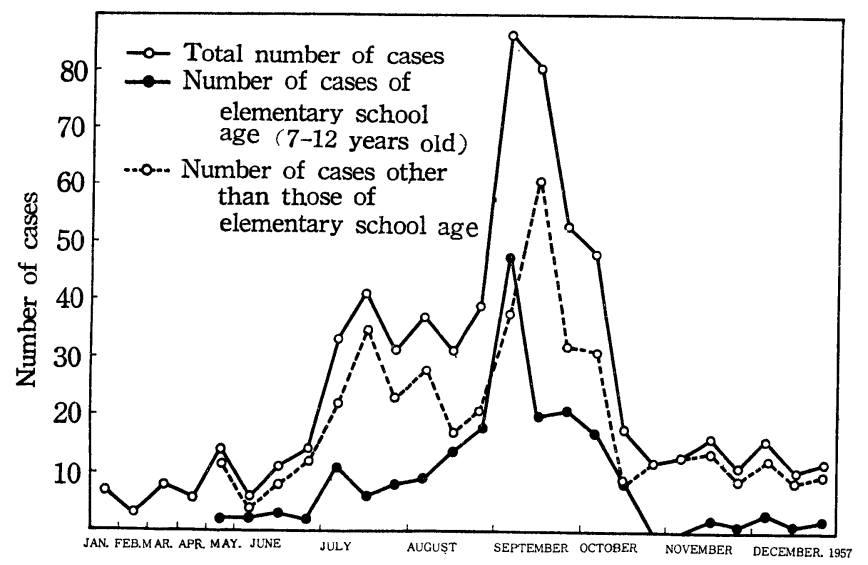

Fig. 3. Time-occurrenc of cases of adenovirus type 8 infections picked up from the protocols of the four ophthalmological hospitals in Ogaki City.

The numbers are plotted according to the dates on which the patients called ophtnalmologists.

thus picked up, among whom 924 were living in the city, while 161 outside of it. Some of the school children were of course included in them. Table 3 shows the numbers of patients in the areas of the city in which 10 or more than 10 patients were found during that period (the areas in which less than 10 patients were found are omitted in the table). The time-occurrence of the patients is summarized in Fig. 3, in which the white circles on black line present the total number of the patients and the black ones the number of the patients of elementary school age ( 7 to 12 years old). This figure suggests that there may have been one more epidemic peak in July besides the main peak in the general population, but there was no such peak for the patients of elementary school age.

In order to obtain an information about the intrafamilial attack rate of this disease, a survey was made in the Minami Elementary School in the way that questionaires were given to the school children in one class of the fourth grade and 
Table 4. Comparison of the attack-rates in the families with the attacked school children with those in the families with the not-attacked school children. The data were summarized from the questionaires that had been given the school children of the all classes of the fifth grade and one class of the fourth grade in the Minami Elementary School

\begin{tabular}{|c|c|c|c|c|}
\hline \multirow[t]{2}{*}{ Age groups } & \multicolumn{2}{|c|}{$\begin{array}{l}\text { Families where the school } \\
\text { children given questionaires } \\
\text { were not attacked by } \\
\text { the disease }\end{array}$} & \multicolumn{2}{|c|}{$\begin{array}{l}\text { Families where the school } \\
\text { children given questionaires } \\
\text { fell ill of EKC. }\end{array}$} \\
\hline & Number of patients & $\%$ & Number of patients & $\%$ \\
\hline $0-6$ years old & $0 / 42^{\#}$ & 0.0 & $6 / 22$ & 27.3 \\
\hline $7-12 \quad \prime \prime \prime \prime \prime$ & $6 / 191$ & 3.2 & $89 / 115$ & 77.5 \\
\hline $13-15 \prime \prime \prime \prime \prime$ & $3 / 60$ & 5.0 & $10 / 41$ & 24.4 \\
\hline $16-\quad " \prime \prime \prime$ & $6 / 350$ & 1.7 & $16 / 198$ & 8.1 \\
\hline Total & $15 / 643$ & 2.3 & $121 / 376$ & 32.1 \\
\hline
\end{tabular}

\# Numerator: Number of patients,

Denominator: Number of total members.

The numbers not including the school children whom the questionaires were given.

in all the classess of the fifth grade of the school, to fill in whether they and their household members had been attacked by the disease or not. The results are summarized in Table 4. In those households in which the school children given questionaires had been attacked by the disease during the epidemic period, the rate of morbidity in the household members is much higher than in those families in which the school children given questionaires had not been attacked by the disease. This fact is considered to indicate that a fairly large proportion of the household patients were more or less associated with the school outbreak of the disease, and therefore it is quite compatible with what has been mentioned in the preceding: paragraph.

Table 5. Numbers of patients among school children and their family members

\begin{tabular}{lcc}
\hline School & $\begin{array}{c}\text { Number of patients among } \\
\text { school children }\end{array}$ & $\begin{array}{c}\text { Number of patients among } \\
\text { family members (not including } \\
\text { school children) }\end{array}$ \\
\hline Minami E & 349 & 153 \\
Nishi E & 203 & 103 \\
Other 8 Es & 142 & 50 \\
Minami M"\# & 104 & 60 \\
Other 4 Ms & 81 & 19 \\
\hline Total & 879 & 385 \\
\hline
\end{tabular}

\# E : Elementary School

\#\# M: Middle School 
Table 5 gives us rough informations as to how many persons were involved in the epidemic beside school children. The table shows the numbers of the patients among the school children and those among the household members of the school children in the given schools. It is herefrom presumed that about as half as or a little less than the number of the patients among school children were involved in the outbreak.

The area-specific attack-rate was estimated by the survey of the school children in the Minami Elementary School. The district for this school is mainly divided into 13 areas where the houses of its school children were located. The number of the school children involved in the epidemic in each area and the attack-rate

Table 6. Numbers of the children attacked by the disease and the attack rate in the areas of the Minami Elementary School district

\begin{tabular}{|c|c|c|c|}
\hline Area & $\begin{array}{l}\text { Numbers of school } \\
\text { children living } \\
\text { in the areas }\end{array}$ & $\begin{array}{l}\text { Numbers of school } \\
\text { children attacked }\end{array}$ & $\begin{array}{l}\text { Percentage } \\
\text { attack rate }\end{array}$ \\
\hline Oike & 58 & 14 & 24.2 \\
\hline Miwa & 199 & 34 & 17.1 \\
\hline Yoyasu & 148 & 25 & 16.9 \\
\hline Funa & 22 & 5 & 22.7 \\
\hline Jinai & 392 & 77 & 19.6 \\
\hline $\mathrm{Ta}$ & 103 & 19 & 18.4 \\
\hline Tawara & 69 & 11 & 15.9 \\
\hline Takejima & 91 & 18 & 19.8 \\
\hline Imaoka & 42 & 12 & 28.6 \\
\hline Minaminokawa & 285 & 64 & 22.5 \\
\hline Noginomori & 41 & 13 & 31.7 \\
\hline Shin & 141 & 28 & 19.9 \\
\hline Minamitakahashi & 73 & 16 & 21.9 \\
\hline Others & 49 & 8 & 26.5 \\
\hline Total & 1713 & 349 & 20.4 \\
\hline
\end{tabular}

calculated therefore for each area are given in Table 6 . The attack-rate varies, as seen there, from 31.7 to 15.9 with an average of 20.1 but the variation is not so marked.

The variation in the class-specific attack-rate was also not marked as shown in Table 7, though a little more marked than in the area-specific attack-rate. The values were within a range of 32.7 to 7.7 with an average of 20.9. As has been mentioned in a previous paragraph, it is suggested that a major part of the epidemic of the disease was played by school children, but it is considered that the variation in the class-specific attack-rate may have been too small to be explained only by the transmission mode of person-to-person contacts among school children. The same is suggested also about person-to-person contacts among household members, which alone could not explain the smallness of the variation in the area- 
Table 7. Class-specific attack rate in the Minami Elementary School

\begin{tabular}{|c|c|c|c|c|c|c|c|c|c|c|c|c|}
\hline \multirow{3}{*}{ Class } & \multicolumn{12}{|c|}{ Grade in school } \\
\hline & \multicolumn{2}{|l|}{ I } & \multicolumn{2}{|l|}{ II } & \multicolumn{2}{|l|}{ III } & \multicolumn{2}{|l|}{ IV } & \multicolumn{2}{|l|}{$\mathrm{V}$} & \multicolumn{2}{|l|}{ VI } \\
\hline & Number & $\%$ & Number & $\%$ & Number & $\%$ & Number & $\%$ & Number & $\%$ & Number & $\%$ \\
\hline 1 & $12 / 49^{\#}$ & 24.5 & $17 / 52$ & 32.7 & $8 / 53$ & 15.1 & $20 / 57$ & 35.1 & $15 / 54$ & 27.8 & $13 / 47$ & 27.2 \\
\hline 2 & $12 / 50$ & 24.0 & $4 / 52$ & 7.7 & $12 / 52$ & 23.1 & $6 / 57$ & 10.5 & $16 / 55$ & 29.1 & $12 / 47$ & 25.5 \\
\hline 3 & $9 / 49$ & 18.0 & $10 / 53$ & 18.9 & $9 / 52$ & 17.3 & $13 / 57$ & 22.8 & $11 / 55$ & 20.0 & $12 / 46$ & 26.1 \\
\hline 4 & $10 / 48$ & 20.8 & $11 / 52$ & 21.2 & $13 / 51$ & 25.5 & $11 / 57$ & 19.3 & $8 / 55$ & 14.5 & $10 / 46$ & 21.7 \\
\hline 5 & $5 / 48$ & 10.4 & $5 / 54$ & 9.3 & $17 / 55$ & 30.9 & $11 / 57$ & 19.3 & & & & \\
\hline 6 & $4 / 47$ & 8.5 & $9 / 53$ & 17.0 & $9 / 52$ & 17.3 & $15 / 57$ & 26.3 & & & & \\
\hline Total & $52 / 291$ & 17.9 & $56 / 316$ & 17.7 & $68 / 315$ & 21.6 & $76 / 342$ & 22.2 & $50 / 219$ & 21.9 & $47 / 186$ & 25.3 \\
\hline
\end{tabular}

\# Numerator : Attacked children

Denominator : Total children

specific attack-rate. Thus, it is presumed that there might have been a common source of infection in each of the schools involved which caused a main part of the epidemic in them. This point was investigated for the epidemic in the Minami Elementary School, where questionaires were given to the school children in 4 classes of the fifth grade and in one class of the fourth grade in order to obtain informations about the relationships between the attack-rate and some factors which might have been a possible source of infection, for example using a public bath-house or not, using a washing towel in common in a household or not, frequency of taking a bath, using a bed in common with their brothers or not, using a swimming pool or not, and its frequency if using it etc. The survey results are summarized in Table 8 . There is no difference between attacked and not-

Table 8. Factors possibly affecting the attack rate

\begin{tabular}{|c|c|c|c|c|}
\hline \multirow{2}{*}{ Factors } & \multicolumn{2}{|c|}{$\begin{array}{l}\text { School children not } \\
\text { attacked }\end{array}$} & \multicolumn{2}{|c|}{$\begin{array}{l}\text { School children } \\
\text { contracting illness }\end{array}$} \\
\hline & Number & $\%$ & Number & $\%$ \\
\hline Using a public bath-house & $71 / 117^{\#}$ & 60.5 & $42 / 70$ & 59.9 \\
\hline Using a public bath-house every day & $33 / 117$ & 28.2 & $18 / 70$ & 25.7 \\
\hline $\begin{array}{l}\text { Using a washing towel in common } \\
\text { with other family members }\end{array}$ & $66 / 117$ & 56.4 & $39 / 70$ & 57.0 \\
\hline $\begin{array}{l}\text { Using a bed in common with other } \\
\text { family members }\end{array}$ & $74 / 117$ & 63.2 & $43 / 70$ & 61.2 \\
\hline Swimming in the pool & $74 / 117$ & 63.2 & $61 / 70$ & 86.0 \\
\hline $\begin{array}{l}\text { Swimming in the pool more than ten } \\
\text { times }\end{array}$ & $52 / 117$ & 44.4 & $50 / 70$ & 71.5 \\
\hline
\end{tabular}

\# Numerator : Number of children corresponding to each item in the column "Factors". Denominator: Total number of children. 
Table 9. Situation as to water renewal in the swimming pools in schools and $E$. coli counts

\begin{tabular}{llccc}
\hline School & Water renewal & $\begin{array}{c}\text { E. coli count (MPN) } \\
\text { at the time (see } \\
\text { the next two } \\
\text { columns) }\end{array}$ & $\begin{array}{c}\text { Date of } \\
E \text {. coli } \\
\text { counts }\end{array}$ & $\begin{array}{c}\text { Number of persons } \\
\text { swimming in the pool } \\
\text { from water renewal } \\
\text { till water examination }\end{array}$ \\
\hline Nishi E. ${ }^{*}$ & $\begin{array}{l}\text { every five days } \\
\text { Minami E. }\end{array}$ & 0 & August 26 & 71 \\
\hline
\end{tabular}

\# E : Elementary School

attacked children in such factors as the usage of a public bath-house, the frequency of bathing, the common use of a washing towel, the common use of a bed, but a significant difference is seen between the both groups of the children in respects of the usage of the swimming pool and its frequency. Among the ill children 86.0 per cent used the swimming pool of the school, while 63.2 per cent among the not-attacked children used it. Furthermore, 71.5 per cent of the ill children swam in it more than 10 times, whereas it was 44.4 per cent of the not-attacked children who swam in it more than 10 times. Thus, it is fairly probable that a common source of infection which is supposed to have played a major role in causing the epidemic was the swimming pool in the school, at least in the Minami Elementary School. As the swimming pool in a school is usually used by a very large number of school children, it is very apt to be polluted by them, and if there were among them those, who were or had been infected with adenovirus type 8 , the virus was. likely to pollute swimming pool water by excretion from infected eyes or stools. Table 9 shows an example of the results of water pollution examinations for the swimming pools in the Nishi and the Minami Elementary Schools. In these swimming pools the water was stated to be renewed every five days in the Nishi and every three days in the Minami Elementary Schools. It is to be noticed that water pollution examination revealed $20 \mathrm{MPN}$ for $E$. coli counts in the pool of the Minami. Elementary School, after 1,570 children took a swimming.

The incubation period: The incubation period of the disease was estimated from the interval between the dates of two patients occurring in a single house-

Table 10. Intervals between the onsets of the first and the next patients in a single household

\begin{tabular}{ccc}
\hline Intervals (days) & Number of examples & Percentage $(\%)$ \\
\hline $0-4$ & 2 & 5.5 \\
$5-9$ & 17 & 47.2 \\
$10-14$ & 12 & 33.4 \\
$15-19$ & 1 & 2.8 \\
$20-24$ & 1 & 2.8 \\
$25-29$ & 3 & 8.3 \\
\hline Total & 36 & 100.0 \\
\hline
\end{tabular}


hold, by examining protocols presented by three ophthalmological hospital in the epidemic area. The results are summarized in Table 10, which shows that most of the second patients in families fell ill 5 to 14 days after the onset of the first patients.

Clinical varieties: The frequencies of some clinical symptoms shown by the patients were estimated from the protocols of patients examined in three ophthalmological hospitals, as shown in Table 11.

Table 11. Frequency of certain clinical symptoms in the patients of epidemic keratoconjunctivitis examined

\begin{tabular}{lccc}
\hline \multicolumn{1}{c}{ Symptom } & $\begin{array}{c}\text { Number of patients } \\
\text { examined }\end{array}$ & $\begin{array}{c}\text { Number of patients } \\
\text { having the symptom } \\
\text { in question }\end{array}$ & $\begin{array}{c}\text { Percentage } \\
(\%)\end{array}$ \\
\hline Conjunctival hyperaemia & 471 & 471 & 100 \\
Conjunctival swelling & 466 & 423 & 90.8 \\
Follicles & 471 & 453 & 96.2 \\
Increased eye secretion & 470 & 463 & 98.7 \\
Conjunctival haemorrhage & 452 & 102 & 22.6 \\
Conjunctival oedema & 450 & 198 & 44.0 \\
Pseudomembrane & 449 & 119 & 26.5 \\
Enlargement of preauri- & 319 & 97 & 30.4 \\
$\quad$ culary lymph nodes & 456 & 90 & 19.7 \\
Keratitis & 386 & 3 & 0.8 \\
Coryza & 289 & 3 & 1.0 \\
Fever & & &
\end{tabular}

\section{LABORATORY EXAMINATION}

Materials were obtained from the eyes of nine patients in an ophthalmological hospital by the method described in Laboratory Methods, and submitted to virus isolation by means of $\mathrm{HeLa}$ cell inoculation. Out of ten materials from the nine patients 6 strains of adenovirus were isolated, as seen in Table 12. These strains were all identified as type 8 by comparing their antigenic pattern with that of the prototype of type 8 adenovirus by neutralization reaction. The cytopathic changes of HeLa cells seemed to appear fairly slowly in the cultures inoculated with the eye materials compared with those of the other types of adenoviruses, especially those of type 1 , type 2 , type 3 , type 5 and type 7 adenovirus, according to our experiences. For example, in the case of the material No. 140 (in Table 11), that is the case in which cytopathic changes were seen in the shortest incubation, it was 13 days after the inoculation when cytopathic changes suspected of adenovirus type 8 were observed for the first time. In another case, in which the changes appeared most retardedly, they were observed for the first time 22 days after the inoculation. Furthermore, the spread of the cytopathic lesions was very slow compared with that of other types of adenoviruses. In the case of the material No. 140 , though a few foci were already noticed 13 days after the inoculation, as 
Table 12. Patients subjected to virus iso-

\begin{tabular}{|c|c|c|c|c|c|c|c|}
\hline $\begin{array}{l}\text { Case } \\
\text { No. }\end{array}$ & Nome & Sex & Age & $\begin{array}{l}\text { Involved } \\
\text { eye }\end{array}$ & $\begin{array}{l}\text { Date of first } \\
\text { hospital visit }\end{array}$ & $\begin{array}{l}\text { Date of onset } \\
\text { of illness }\end{array}$ & $\begin{array}{l}\text { Palpebral } \\
\text { swelling }\end{array}$ \\
\hline No. 1 & & female & 41 & right & 25 September & 23 September & + \\
\hline No. 2 & & female & 8 & left & 20 September & 18 September & + \\
\hline No. 3 & & female & 11 & right & 23 September & 23 September & + \\
\hline No. 4 & & male & 14 & right & 26 September & 21 September & \pm \\
\hline No. 5 & & male & 8 & left & 23 September & 21 September & + \\
\hline No. 6 & & female & 11 & left & 27 September & 27 September & + \\
\hline No. 7 & & female & 14 & right & 27 September & 26 September & \pm \\
\hline No. 8 & & female & 15 & both & 26 September & 25 September & - \\
\hline No. 9 & & male & 9 & right & 27 September & 25 September & + \\
\hline
\end{tabular}

mentioned above, they were still fairly restricted in their extent, in spite of weekly medium changes.

Among the patients listed in Table 12 , the patients (No. 3), (No. 4), (No. 4), (No. 5),
(No. 6) and (No. 2), (No. 7) and (No. 8) were students of the Minami Middle School. The patient (No. 1) was the mother of a patient attending the Minami

Table 13. Serological examinations of patients' sera at acute and convalescent stages

\begin{tabular}{|c|c|c|c|c|c|c|}
\hline \multirow{2}{*}{$\begin{array}{l}\text { Case } \\
\text { No. }\end{array}$} & \multirow{2}{*}{ Name } & \multicolumn{3}{|c|}{ Acute stage } & \multicolumn{2}{|c|}{ Convalescent stage } \\
\hline & & $\begin{array}{r}\text { Time } \\
\text { coll }\end{array}$ & $\begin{array}{l}\text { ferum } \\
\text { etion }^{\#}\end{array}$ & $\begin{array}{c}\text { Neutralization } \\
\text { titer }\end{array}$ & $\begin{array}{l}\text { Time of serum } \\
\text { collection }\end{array}$ & $\begin{array}{c}\text { Neutralization } \\
\text { titer }\end{array}$ \\
\hline 4 & & & $\operatorname{ay}(\mathbf{s})$ & $<1: 2$ & $c a .4$ months & $<1: 2$ \\
\hline 5 & & 7 & $\prime \prime$ & $<1: 2$ & ca. 4 months & $1: 16$ \\
\hline 6 & & 1 & $\prime \prime$ & $<1: 2$ & 14 days & $1: 4$ \\
\hline 7 & & 2 & $\prime \prime$ & $<1: 2$ & ca. 4 months & $<1: 2$ \\
\hline 8 & & 3 & $\prime \prime$ & $<1: 2$ & ca. 4 months & $1: 4$ \\
\hline 9 & & 3 & $\prime \prime$ & $<1: 2$ & ca. 4 months & $1: 4$ \\
\hline 10 & & 6 & $\prime \prime$ & $<1: 2$ & 16 days & $1: 16$ \\
\hline 11 & & 5 & $\prime \prime$ & $<1: 4$ & $10 \quad / \prime$ & $1: 8$ \\
\hline 12 & & 3 & $\prime \prime$ & $<1: 2$ & $27 \quad \prime \prime$ & $1: 32$ \\
\hline 13 & & 8 & $\prime \prime$ & $<1: 2$ & $18 \quad \prime \prime$ & $1: 8$ \\
\hline 14 & & 1 & $\prime \prime$ & $<1: 2$ & 29 & $1: 8$ \\
\hline 15 & & 7 & $\prime \prime$ & $<1: 2$ & 19 & $1: 8$ \\
\hline 16 & & & & $<1: 2$ & & $1: 8$ \\
\hline
\end{tabular}

\# days or months after the onset of illness 
lation and the results of virus isolation

\begin{tabular}{|c|c|c|c|c|c|c|}
\hline $\begin{array}{l}\text { Enlargement } \\
\text { of preauri- } \\
\text { culary } \\
\text { lymph nodes }\end{array}$ & $\begin{array}{l}\text { Follicle } \\
\text { formation }\end{array}$ & $\begin{array}{l}\text { Pseudo- } \\
\text { menbrane } \\
\text { formation }\end{array}$ & $\begin{array}{l}\text { Specimen } \\
\text { No. }\end{array}$ & $\begin{array}{l}\text { Date of } \\
\text { specimen } \\
\text { collection }\end{array}$ & Virus & $\begin{array}{c}\text { Adenovirus } \\
\text { type }\end{array}$ \\
\hline+ & + & - & 136 & 25 September & - & \\
\hline- & + & + & 137 & 25 September & - & \\
\hline \pm & $H$ & - & 138 & 25 September & - & \\
\hline - & $H$ & \pm & $\begin{array}{l}140 \\
145\end{array}$ & $\begin{array}{l}26 \text { September } \\
27 \text { September }\end{array}$ & + & $\begin{array}{l}8 \\
8\end{array}$ \\
\hline$H$ & $H$ & \pm & 141 & 27 September & + & 8 \\
\hline- & + & - & 142 & 27 Septembes & + & 8 \\
\hline+ & $H$ & - & 143 & 27 September & + & 8 \\
\hline+ & + & + & 144 & 27 September & - & \\
\hline$H$ & + & - & 146 & 27 September & + & 8 \\
\hline
\end{tabular}

Elementary School. Virus was isolated from the patient Y. Asano twice, namely both five and six days after the onset of his illness.

Sera were also collected from thirteen patients in the same ophthalmological hospital at both acute and convalescent stages and submitted to the examination of antibody response by means of adenovirus type 8 neutralization reaction. The results are shown in Table 13. The antibody responses were relatively low in these cases compared with those against other types of adenoviruses. The neutralizing antibody titer in acute stage was less than $1: 2$ in all cases but one (the case H. Mabuchi, No. 11), whereas the titer in convalescent stage was $1: 4$ to $1: 32$ in most cases except for two cases, in which no neutralizing antibody was detected in their convalescent serum. It is to be noticed that these two cases were confirmed by virus isolation to be ill of type 8 adenovirus infection, as seen in Table 12. Among the cases listed in Table 13, the patients K. Yoshida (No. 10) and Y. Yamada (No. 13) were students in the Minami Elementary School, the patient K. Murakami (No. 16) was a student in Minami Middle School, while the others were, except for those listed in Table 12, adult patients some of whom were in a honsehold where there were ill school children, but the others of whom were not.

\section{Discussion}

It seems certain that the epidemic prevailing in Ogaki City in the autum of 1957, was due to epidemic keratoconjunctivitis from the ophthalmological and epidemiological viewpoint. Adenovirus type 8 was recovered from eye materials of five among nine patients examined. Furthermore, eleven among thirteen patients were evidenced to show antibody rise against type 8 adenovirus at convalescent stage. These facts are considered to confirm that the adenovirus type 8 is the causative agent or at least one of the causative agents of epidemic keratoconjunctivitis

According to the survey results described in literatures concerning epidemic 
keratoconjunctivitis, several modes of transmission are known to contribute the spread of the causative agent, for example, person-to-person contacts, spreads in dispensaries, transmissions through welding hoods and goggles (Hogan, 1957), swimming pools (Tanaka, 1957) and so forth. In the epidemic of this disease in Ogaki, our survey results suggest that the major factor for the transmission might have been swimming pools that were polluted by some of the sporadic cases who constituted the basic ground of the epidemic. This situation is clearly seen in Fig. 3. The epidemic peak, which lies at about the beginning of September, is presumed to have been induced by swimming pool contaminations, and already before this peak, a considerable number of cases were seen among school children in addition to the small epidemic peak preceding the main in the general population. Fig. 3 also clearly shows that the main peak in the general population occurred a little delayed compared with that of the patients of elementary school age, and this fact may possibly mean that those children who had caught ill during the main peak that was supposed to be due to swimming pool contaminations might have become infective centred in their households or some other circumstance of their civil lives.

\section{SUMMARY}

The epidemic of epidemic keratoconjunctivitis occurring in Ogaki City was confirmed to be due to adenovirus type 8 by virus isolation and serological findings.

The main event of the epidemic seems to have been the outbreaks among the school children which are supposed to have been caused by swimming pool contaminations, ibut cases were already seen in the several preceding months and continued to be seen still several months after the main event.

Appreciations are exprssed to Drs. Masao Kondo, Itsuo Sugitani, Yuzo Uchida, Toshiko Yanagiwara and Yataro Aoki for letting us collect valuable materials from their hospital protocols, and further to Dr. Yataro Aoki for helping us to collect virological and serological specimens from cases in his hospital.

\section{REFERENCES}

Fukumi, H., Nishikawa, F., Nakamura, K., Watanabe, T. \& Kitayama, T. (1958) : Further studies of the cases associated with adenoviruses. Jap. J. M. Sc. \& Biol., 10, 407-418.

HOGAN, M. J. (1957): Keratoconjunctivitis. The clinical characteristics of the California epidemic, 1940-1942. Am. J. Ophth., 43, (No. 4, Part II), 41-44.

Jawetz, E., Kimura, S. J., Hanna, L., Coleman, V. R., Thygeson, P. \& Nicholas, A. (1955): Studies on the etiology of epidemic keratoconjunctivitis. Am. J. Ophth., 40, 200-209.

Jawetz, E., Kimura, S. J., Nicholas, A. N., Thygeson, P. \& Hanna, L. (1955) : New type of APC virus from epidemic keratoconjunctivitis. Science, 122, 1190-1191.

Jawetz, E., Thygeson, P., Hanna, L., Nicholas, A. \& KimUrA, S. J. (1957): The etiology of epidemic keratoconjunctivitis. Am. J. Ophth., 43, (No. 4, Part II), 79-83.

LEOPOLD, J. H. (1957): Characteristics of hospital epidemics of epidemic keratoconjunctivitis. Am. J. Opth., 43, (No. 4, Part II), 93-97.

Mitsui, Y., Hanabusa, J., MinOdA, R. \& OGata, S. (1957): Effect of inoculating adenovirus (APC virus) type 8 into human volunteers. Am. J. Ophth., 43, (No. 4, Part II), 84-90. 
Mitsui, Y. \& JAWETZ, E. (1957): Isolation of adenovirus type 8 (APC type 8) from a case of epidemic keratoconjunctivitis in Japan. Am. J. Ophth, 43, (No. 4, Part II), 91-93.

SOMMERVILlE, R. G. (1957): Adenoviruses as a cause of epidemic keratoconjunctivitis on Clydeside. Proc. Roy. Soc. Med., 50, 757-758.

SOMMERVILlE, R. G. (1958): Epidemic keratoconjunctivitis - an adenovirus infection. J. Hyg., 56, 101-107.

TANAKA, C. (1957): Epidemic keratoconjunctivitis in Japan and the Orient. Am. J. Ophth., 43, (No. 4, Part II), 46-50. 